\title{
BOSNIAN ENLIGHTENER STAKA SKENDEROVA: A WOMAN AHEAD OF HER TIME ${ }^{1}$
}

\begin{abstract}
:
The article deals with the outstanding Bosnian enlightener Staka Skenderova (1830-91). She was the author of the essay The Annals of Bosnia. In 1858 Skenderova opened a school for girls in Sarayevo, where representatives of all faiths were admitted. This school received assistance from Russia, Serbia and from the Ottoman Sultan Abdul Aziz.

Keywords:

Staka Skenderova, a school for girls, Sarayevo, A.F. Hilferding, A.D. Bludova, Abdul Aziz.

АННОТТЦИЯ: К.В. МЕЛЬЧАКОВА. «БОСНИЙСКАЯ ПРОСВЕТИТЕЛЬНИЦА СТАКА СКЕНДЕРОВА ЖЕНЩИНА, ОПЕРЕДИВШАЯ СВОЕ ВРЕМЯ».

В статье идет речь о выдающейся боснийской просветительнице Стаке Скендеровой (1830-91). Она является автором сочинения “Летопись Боснии”. В 1858 г. Скендерова открыла в Сараево школу для девочек, куда принимали представительниц всех вероисповеданий. Это учебное заведение получало помощь из России, Сербии и от самого султана Османской империи Абдул Азиза.
\end{abstract}

\section{Ключевые слова:}

Стака Скендерова, школа для девочек, Сараево, А. Гильфердинг, А. Блудова, Абдул Азиз.

Staka Skenderova (1830-91) was one of the first representatives of wo$\checkmark$ men's emancipation in the Balkans, Bosnian educator, founder of the first school for girls in Bosnia, polyglot, first female Bosnian author of a historical review on Bosnia.

For Bosnian society of the 19th century, Staka Skenderova was a truly extraordinary phenomenon. She was born into a patriarchal Bosnian environment, full of prejudices and rules of behavior incomprehensible to European society, but did not assimilate to it. She mastered several languages - Serbian, Turkish, Greek, Russian, sang in the church choir, dressed in dark-colored men's clothing, won an audience with the Turkish Sultan, Abdul-Aziz, independently made a pilgrimage to Jerusalem, engaged in literary work and opened a school for girls in Bosnia. She was a nun in a city where there was not a single Orthodox monastery and spent most of her life working in a secular field, earning the respect of her contemporaries and subsequent generations.

\footnotetext{
1 The work was carried out with the financial support of the RFBR (grant № 18-512-76004).
} 
The story of her life reads like a novel. She was from an Orthodox Savichev family (according to another version, Petrovich or Damyanovich), which in Bosnia began to be called Skanderovs, because they moved there from Skadar sanjak. Staka was born in Sarayevo, where she very quickly mastered reading and writing, which was rare for a girl in that part of the country.

From a young age, her father dressed her in men's clothing, as Christians and Muslims living in Bosnia often did with their young daughters. She continued this habit throughout her life, and this was one sign of her renunciation of marriage. In it, she attended church, where she read from the Book of Acts, for there was not a single competent young man in the district.

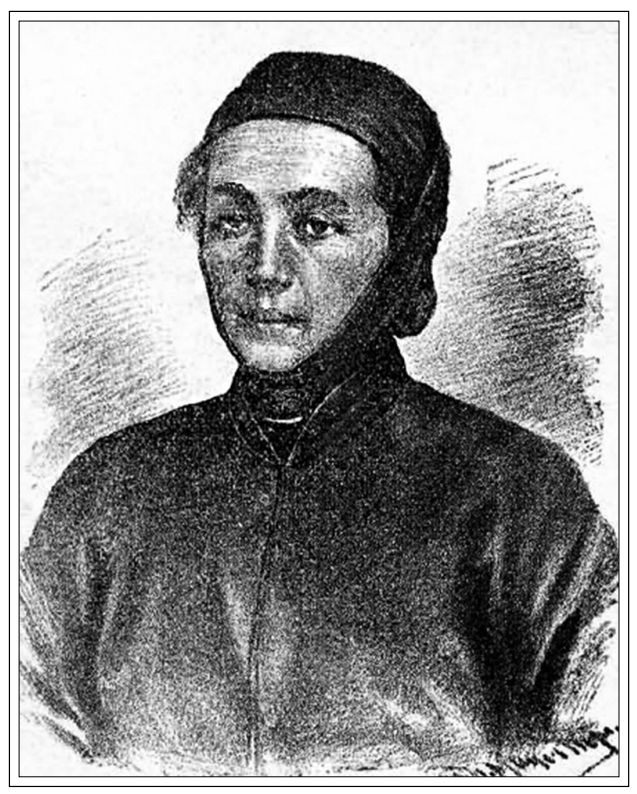

Staka Skenderova

She assisted her elder brother, who was engaged in dressing and selling furs to Bosnian merchants, Turkish officials and the military. While delivering orders, Staka went to many Turkish houses, and as the result she learned Turkish and became acquainted with representatives of the local Turkish nobility. This turned out to be very useful in instances of conflict between Muslims and Christians, in which Staka defended the interests of her co-believers.

Staka Skenderova attracted the attention of the first Russian consul in Sarayevo, A. F. Hilferding, who invited her to write a work about the history of Bosnia during the period 1825-56, which he later translated into Russian and published. Unfortunately, the Serbian original of her work was not preserved. Staka created her Annals of Bosnia in a poetic form, stylistically likening it to a folk epic, but A. F. Hilferding translated the work into Russian in prose form. Only the original Serbian poetical text of the author which the translator placed in footnotes has reached us. The chronicle describes the history of struggle of the Bosnians against the Turkish pashas and tells about the severe suffering of ordinary Bosnians under the tyranny of the local nobility.

It also tells the tragic story of Staka's younger brother Jovan. He was a wonderful, educated young man; he knew Turkish, played the violin, tambourine and pipes and worked as a furrier. Everything was going well, but the young man died because of slander by a Turk; i.e., he was falsely accused by a Bosnian Muslim of attacking him with a knife during evening prayer. The reason for the malicious slander was the Turk's jealousy of Jovan because of the girl he liked. The complaint came to the local official, Fazli Pasha, who was not kindly remembered 
after his death. He was infamous among Bosnians for his evil disposition and unconcealed hatred of Christians, and without conducting a trial, he ordered that the young man be burned with a red-hot iron and then thrown into prison. Left a destroyed man by the torture he'd experienced, Jovan survived for only about two years after his release.

Staka Skenderova's cherished dream was to open a school for girls. In 1858, this dream was realized with the assistance of a number of Russian and Serbian public and political figures. Among them the aforementioned A. F. Hilferding played an important role. Staka appealed to him for help, and he responded to her request, especially since she, as the petitioner, had mentioned that a main goal of the school was introducing children to Christianity. Upon his return to St. Petersburg, Hilferding secured a school allowance from the Russian government amounting to 1384 rubles. The Russian Empress Maria Alexandrovna also made a donation at the time in the amount of 1400 rubles.

On opening the school, Staka was immediately met with opposition from the patriarchal Serbian social milieu and with mistrust by Sarayevo's Orthodox community. Since she was actively supported by a prominent Ottoman official, Veliudin Pasha, many Orthodox parents refused to send their daughters to a school patronized by the Turkish authorities.

In September 1858 she went to Belgrade, where she was assisted by a Russian aristocrat, Countess Antonina Dmitrievna Bludova. It was the countess who helped her find a suitable teacher for the school. In Belgrade, Staka not only acquired a set of books necessary for the school, but also won the favor of the Serbian Metropolitan Peter, who himself attended the grand opening on 18 October 1858, offering a prayer service, sprinkling holy water on the building and blessing the children's study. The patron of science and education, St Sava of Serbia, was selected as the new school's patron.

The school was situated in a small two-story building, the first floor of which was occupied by Skenderova's family; on the second floor there was a large spacious classroom, a small room for needlecraft and Staka's office, where she prayed.

The school's curriculum included the study of arithmetic, Serbian history, reading and writing, horology, hymns and church singing. In addition, the girls were taught needlework, which attracted even the skeptical prosperous citizens.

Only students from wealthy families paid for their studies. With the funds received, materials were purchased for needlework (silk and gold thread). For poor children, Staka was not only their teacher, but also their protector. Many orphans relied entirely on her for their maintenance. She was their mother, feeding, clothing and raising them. Staka even took on the upbringing of those girls whose mothers resided in brothels, opening up for them new prospects. She was known as a strict but fair teacher. Her students feared her censure more than they did corporal punishment. 
At the end of the school year, public examinations were held, which were attended by the Bosnian Pasha himself (or his deputy), church representatives and the parents of the students. Every year they organized exhibitions of handicrafts, of which the school was proud and justifiably renowned. On Sundays and public holidays, a choir of students performed in the church under Skenderova's direction.

The doors of the school were open to children of all faiths. Girls from Orthodox, Catholic, Jewish and Muslim families studied on equal terms.

Despite difficulties and the hostility of the Sarayevo merchants and the Orthodox community, the school under S. Skenderova's leadership continued to exist. In 1858 there were 75 girls attending classes, and in August 1861 - already 120. The fame of the school spread throughout the Bosnian pashalyk.

Upkeep of the school was expensive. Skenderova submitted her accounts to the Russian consul. Considerable amounts were used to pay taxes, and the school's income was consequently small.

Three years after its opening, the school began to receive regular financial assistance from the Turkish government. Staka's school was visited by the Governor-General of the Bosnian pashalyk, Topal Sherif Osman Pasha, and after familiarizing himself with its educational principles, he sent his daughters to be trained there. Other Turkish officials followed his example.

By 1865 the school's financial situation was deplorable: its debts amounted to about 19,000 piastres, and so it had to move to a more modest, unfinished house. Deprived of shelter and persecuted by the Orthodox community, Staka found temporary shelter in the house of an Orthodox widow in Sarayevo. Help came from Russia: Staka received 1000 piastres necessary to construct a building, however, the debts that had accumulated remained unpaid.

In autumn 1865 Staka sent a petition requesting assistance to travel to Russia in order to raise money to pay off debts and to establish women's schools in Bosnian cities. Russian Empress Maria Alexandrovna responded positively to this petition, but Staka had to wait for more than a year to receive permission for this trip. During this time, the school's debts increased significantly, and the petitioner did not have the money to travel to Russia.

In 1870 Skenderova set off on her journey, however, not to Russia, but to Jerusalem, to the Holy Sepulchre. Her route lay through Constantinople, and the former Governor of the Bosnian Vilayet, Topal Sherif Osman Pasha, obtained for her an audience with Sultan Abdul Aziz and payment of travel expenses in the amount of 10,000 groschen. Upon arriving in the Holy Land, Staka took monastic vow. Her trip lasted an entire year, and it was an unheard-of event for that time. In Bosnian society it was considered indecent for women to attend weekday worship services unaccompanied by family members or a male escort. In her case, Staka had ventured to the Holy Land alone and had even deigned to meet with the Sultan himself. Staka's return to Sarayevo was triumphant, and crowds of people came out to greet her. 
After the Austro-Hungarian occupation of Bosnia and Herzegovina in 1878, the school had to be shut down due to the cessation of monetary assistance from the Sultan and a lack of funds from Russia. The new authorities showed no interest in the operation of such an institution. The English philanthropist, Miss Adeline Paulina Irby, took over the custody of the orphans. At one time, she too had opened a school for girls in Sarayevo and had faced the same problems as Skenderova. Many believed that the new school would compete with Staka's school, but the latter, in her speeches to the church community, emphasized the importance of education and explained the purely educational nature of the English woman's intentions. The women became friends, and when Staka found herself in difficult straits, Paulina took on supporting her together with Staka's elderly mother for the rest of their lives.

Graduates of the Skenderova school were the first educated women of Bosnia and Herzegovina. They were considered to be very eligible brides, and they married well. They brought up their children in the spirit of the new time, instilling in them a desire for learning and a different culture.

Until the end of her days, Staka never ceased helping people. On 26 May 1891 she had an accident while leading two of her pupils from poor families home after a holiday in Sarayevo for the benefit of the poor and orphans. On the way back they were hit by a horse-drawn carriage. The children miraculously were not hurt, however, Staka was fatally injured. The next day the accident victim died in a city hospital. Paulina Irby took care of all the expenses and problems associated with Staka's burial. After Staka's death, she regularly visited the cathedral, lighting candles in memory of her friend.

The circumstances of the opening and operation of Staka Skenderova's school in Sarayevo provide vivid examples of confessional ethnic tolerance in Bosnia and the solidarity on the part of Serbs, Russians, Turks and the English.

\section{Translated by Igor Kaliganov}

\section{BIBLIOGRAPHY}

Hadži Staka Skenderova i srpska kultura u Bosni i Hercegovini. Tematski zbornik. Banjaluka, 2017.

Hawkeswoth $S$. Voices in the Shadows. Women and Verbal Art in Serbia and Bosnia. CEU-PRESS, 2000. Pp. 250-52.

Irby J.T. Meeting Miss Irby. Sarajevo; Zagreb, 2011.

KršićJ. Hadži Staka Skenderova // Politika. 6 januar 1932.

Popović A. Hadži Staka Skenderova, srpska kaluherica i učiteljica // Bosanska vila. 1903. N 23-24. S. 393-95.

Skenderova S. Letopis' Bosnii 1825-1856 // Sobranie sochineniǔ A. Gil'ferdinga. Tom tretii. Bosniia, Gertsegovina i Staraia Serbiia. SPb., 1873. S. 380-465.

TomaševićD. Majka bosanske sirotinje // Adelina Paulina Irbi, Georgina Mjur Mekenzi. Putovanja u slovenske provincije Turske u Evropi. Sarajevo, 2016. S. 7-24. 